\title{
Cosmolocalism: Understanding the Transitional Dynamics towards Post-Capitalism
}

\author{
Alexandros Schismenos*, Vasilis Niaros** and Lucas Lemos*** \\ *Aristotle University of Thessaloniki, Thessaloniki, Greece, abonapartis@gmail.com \\ **Universitat Oberta de Catalunya, Barcelona, Spain, vniaros@uoc.edu \\ ***Tallinn University of Technology, Tallinn, Estonia, lucasb.lemos@gmail.com
}

\begin{abstract}
Over the last decades, the proliferation of ICTs and capitalist markets has created a new social-historical reality for communication, production and societal organisation, while social inequality has deepened. In this context, alternative forms of organisation based on the commons have emerged, challenging the core values of capitalism. Within this new form of egalitarian and transnational collaborative networks, a new concept of social coexistence has been proposed: cosmolocalism. This article presents the genealogy of cosmolocalism and compares it to previous conceptual universalist reconfigurations, namely cosmopolitanism and internationalism. While the current discourse on cosmolocalism focuses on production and distribution, its political dynamics and limitations remain unexplored. Our ultimate goal is to open a path of inquiry for further reflection and deliberation.
\end{abstract}

Keywords: universalism, cosmopolitanism, cosmolocalism, commons, direct democracy

Acknowledgement: This work was financially supported by the European Research Council (ERC) under the European Union's Horizon 2020 research and innovation programme (grant agreement No. 802512).

\section{Introduction}

Cosmolocalism, or cosmopolitan localism, is a concept that has appeared in the last decades in the field of communications, design and peer production, following the creation and expansion of digital communication networks. It is a way to globally link local communities in networks of shared exchange concerning both production and consumption (Manzini 2015). Cosmolocalism creates a new appreciation of place and reinvents the communal in an open and resilient manner (Escobar 2018). Thus, it transfigures the relation between locality and universality, respecting and promoting local communities across a global network of equal co-existence (Sachs 1992).

Cosmolocalism provides an alternative framework for collaborative production. It aims to create resilience locally by sharing resources globally as 'digital commons'. As Ramos notes: "In very basic terms cosmo-localism describes the dynamic potentials of our emerging globally distributed knowledge and design commons in conjunction with the emerging (high and low tech) capacity for localised production of value" $(2017,65)$.

More than a mode of design and a manner of communication, cosmolocalism reinvents the communal and creates a different mode of sociality based on commonality, innovation, equipotentiality and freedom. To the degree that cosmolocalism creates community, it consequently creates an ethos and a pathos 
(Kioupkiolis 2019). These open up new horizons for the project of social transformation and inspire new, more horizontal and equal forms of societal institution (Schismenos 2019). But are such visions actually feasible? Can cosmolocalism inspire a new form of commonality linking the local and the global by transcending the national level of representation?

It is also questionable as to whether cosmolocalism can lead to a post-capitalist commons transition or will remain a tech trend, ultimately assimilated in the capitalist economy (Ramos 2019). This article attempts to analyse the historical and political connotations of the concept of cosmolocalism and examine it in the context of the commons. We then trace the limits of cosmolocalism on the level of production and highlight its potential in the broader social and political sphere. We also shed light on the potential meanings of cosmolocalism corresponding to broader social-historical phenomena of our time. Specifically, the article builds on the questioning of traditional forms of political representation and social belonging, in conjunction with the withering of the political authority of the nation-state. We argue that cosmolocalism provides an alternative conceptual configuration of the relations between locality and universality that underlines issues of social identity and political authority. This could be the basis for an equalitarian, horizontal and democratic reconception of social coexistence.

The rest of the article is organised as follows: Section 2 presents the conceptual categories that are used as our analytical axis, namely locality and universality. In Section 3 we examine the configuration of the local/universal polarity within three concepts of universalism that were developed in different historical contexts: cosmopolitanism, internationalism and cosmolocalism. Finally, we discuss the challenges cosmolocalism faces and argue for the importance of direct democracy as a political form that enables egalitarian cosmolocalism.

\section{An Operational Pair of Categories}

Etymologically, 'cosmolocalism' unveils the two basic categories it conjuncts; universality (designated by the prefix cosmo-) and locality. We examine them as primary schemata of social self-understanding and belonging, as well as matrixes of particular social imaginary significations, namely social-historical modes of being. Universality and locality are essential to the institution of the individual and society across three levels of socio-historical being:

- the existential - this refers to modes of individual existence such as identity and self-consciousness;

- the social - this refers to modes of collective belonging such as custom and language;

- the political - this refers to modes of social governance such as decision-making institutions and laws.

The distinction between the two schemata is theoretical since the aforementioned levels are intrinsically interconnected in private and public human existence. Every individual is in a way instituted by society, though never completely (Castoriadis 1997). Hence, locality and universality are always interrelated and exist as a duality between two interwoven dimensions of social-historical identification. In every instance, the self-image of society is constituted with reference to both local and universal dimensions. However, their specific content in every historical period changes in accordance with dominant social imaginary significations, transfiguring 
their correlation. The shifting dynamics of their configuration depends on the dominant societal structure of established power relations, sanctified social identities and accepted social norms. For instance, in a world of sovereign nation-states, the jurisdiction of the state is limited locally, whereas in Roman antiquity, the claim of imperial authority was projected universally.

\subsection{Locality}

Locality is a primal existential category. We are all socially local, in the sense that we are born in a local fragment of society, a specific place, and we are psychically attached to a place of origin. Following Heidegger's (1999) thinking, locality is more associated with place than space. Space is mathematical, abstract, quantifiable and theoretically infinite; a concept that bears little resemblance to our experience of existence in the world. Contrarily, place is existentially bound with the individual's sense of self-location in the world and towards the world: "we are bound by body to be in place" (Casey 1998, 104).

Locality is related to personal and social daily temporality. It is the locus of present life, since it provides the daily social environment of the individual, the space of lived experience and the time of co-existence. It is the here-and-now of the individual as a nexus of relations.

In every specific locality, time and space are combined in social relations, customs and forms of first-person communication. These would constitute 'placedness' in Heideggerian terms: "measured against their ordinary representations, time and space are [...] not a coupling of time and space but what is more originary in their belonging together" (Heidegger 1999, 132). Thus, placedness is the existential experience of locality and a constituent of personal memory and lived experience.

As an existential category of self-identity and self-history, locality is also expressed politically in forms of local governance. Historically, most modes of political self-governance have been local, realised in terms of horizontal beingtogether such as autonomous cities and communes. However, we should highlight that only locality has been directly linked to an actual territory, a bordered geographic area defined by an authority's jurisdiction. Thus, locality has been the essential foundation of every mode of political representation. In more expanded forms of political institutions, where state jurisdiction covers more territories and political power is concentrated, local authorities tend to be devoid of decision-making power. Still, they remain necessary as the only means of social identification and representation of a local base.

Locality, thus, is an empirical category that permeates all levels of social being - it constitutes the ground of the existential, the roots of the social, and the territory of the political.

\subsection{Universality}

Universality is the a priori logical condition of every locality. It creates modes of understanding that constitute the ontological condition of both the existential and the social level. Universality is the imaginary dimension of our common being as humans. It is not attached directly to daily personal existence but forms the basis of mutual recognition. Moving beyond our limited, local and personal world, universality is what gives substance to the sense of a common good, a common future and a common responsibility. 
Universality has been treated in the context of ethics (Hare 1991), metaphysics (Armstrong 1989) and human rights (Donnelly 2007). However, as has been pointed out by Balibar (1995), its meaning cannot be constrained to a singular plane, but rather encompasses various concepts.

Universality can be interpreted both as immanent and transcendental. As a transcendental category, it goes beyond our experience, as does the idea of humanity. Simultaneously, as an immanent category, universality is constitutive of our experience. The construction of our personal identities is based on our preidentified belonging to a social world. Universality is thus both the condition of historical consciousness and the logical a priori of every other form of social belonging. It is connected with natural and historical temporality in diverse ways, depending on how a specific society leans on nature and understands history.

Politically, universality forms a horizon of aspiration for emancipatory social movements and the basis of humanism. At the same time, it provides the conceptual foundation for significant historical political decisions such as the enactment of the International Bill of Human Rights in 1948. However, universality can become manipulated and mediated by instituted authorities such as nation-states, as proven by the history of the United Nations (Bresser-Perreira 2008).

Although universality is an imaginary category, it is inextricably interwoven with the empirical category of locality. It is correlated with space, where every actual sense of place belongs. If we start from the empirical point of view of locality, universality forms the imaginary horizon; if we start from the imaginary point of view of universality, locality is its empirical actualisation and individuation.

The following figure summarises the differentiation between the concepts of locality and universality.

\begin{tabular}{|l|l|}
\hline \multicolumn{1}{|c|}{ Locality } & \multicolumn{1}{c|}{ Universality } \\
\hline Actual dimension of 'being here' & Imaginary dimension of common being \\
\hline Personal experience & Mutual recognition \\
\hline Associated with place - 'placedness' & Associated with space \\
\hline Related to personal and social daily temporality & $\begin{array}{l}\text { Related to natural and historical } \\
\text { temporality }\end{array}$ \\
\hline Empirical actualisation and individuation & Imaginary horizon \\
\hline $\begin{array}{l}\text { Constitutes the ground of the existential and the } \\
\text { roots of the social level }\end{array}$ & $\begin{array}{l}\text { Constitutes the ontological condition of } \\
\text { the existential and social level }\end{array}$ \\
\hline Constitutes the territory of the political & $\begin{array}{l}\text { Provides the foundation for historical } \\
\text { political decisions }\end{array}$ \\
\hline
\end{tabular}

Figure 1: The differentiation between 'locality' and 'universality'.

While every community is local, each acknowledges a vast world beyond its boundaries, both geographically and temporally. The community's relation with the external world is dependent on the level of openness of that community towards others. This level conditions the relation between locality and universality: closed communities tend to elevate their locality above every universality, giving fuel to 
xenophobia and chauvinism; open communities strive towards a universal sense of meaning and create appropriate communication infrastructures that transcend locality. In conceptual terms, the former provides the nucleus of localism, which recedes to nativism, whereas the latter is the base of universalism. In classical literature, the city of Sparta would be an example of the former, and Athenian democracy an example of the latter. It was in the social-historical environment of ancient Athens where universalism was first articulated as a theoretical reflection on the human condition.

The next section examines three theories of universalism that have risen in different social-historical contexts but have remained relevant to the present day.

\section{Three Concepts of Universalism}

\subsection{Cosmopolitanism}

Cosmopolitanism is the first theoretical expression of universalism. It originates in the social-historical context of the late Athenian democracy (ca. 404 to $322 \mathrm{BC}$ ), and especially the Macedonian (ca. 335 to 168 BC) and Roman (ca. 27 BC to 476 AD) empires. Diogenes of Sinope, a student of Socrates and the founder of the Cynic philosophical movement, is alleged to have self-identified as a kosmopolites: a citizen of the world. This view marked a significant widening of the concept of citizenship, far beyond its political limits within the locality of a specific city. Diogenes identified virtue as personal independence from all attachments, material or political. However, his aspiration to cosmopolitanism denoted a deeper sense of belonging than the level of locality, which was universal (Nussbaum 1994).

This notion of cosmopolitanism was further explored and theorised by the Stoics. In the context of Stoic philosophy, every human individual "dwells [...] in two communities - the local community of our birth, and the community of human argument and aspiration" (Nussbaum 1997, 3). The Stoics' description of human existence adopted a concentric model, with each individual at the centre surrounded by circles of degrees of affiliation.

Cosmopolitanism arose in the social-historical context of the polis, a political model based on independent and fairly autonomous cities across the Aegean Sea. However, it grew more fully in the social-historical context of the empire. As a multicultural centralised political formation, an empire could lay claim to territorial universality.

The notion of cosmopolitanism was reinvented in Western Europe during the age of the Enlightenment (between the 17th and the 19th centuries), most notably in the work of Immanuel Kant. Following Kleingeld (1999), cosmopolitanism in Germany differentiated several areas of expertise, including morality, culture, legality and economy, wrapped up into a romantic idealisation. Kant envisioned a perpetual peace that would be founded on the universal features of humankind and, even more broadly, on the universality of reason itself. He argued for a law of 'world citizenship' (ius cosmopoliticum) based on the commonality of human beings as citizens that supersedes local legal codes (ius civitatis) and national legislations (ius gentium) in their external mutual relationships (Kant 1795/1991).

According to Kant, this cosmopolitan law exists in terms of mutual hospitality that is founded on the commonality of land-dwelling. Kant stresses our responsibility towards each other, points out that every human being is an end in itself and not a means for other causes, and provides the conceptual basis for universal humanity. Universality is the transcendental condition of human autonomy and dignity. Further, 
Kant expressed in theoretical and analytical terms the emancipation of Western societies from religious heteronomy, which had already inspired the American and French revolutions. The consequent declarations of universal human rights were a decisive institutional self-acknowledgement of humanity beyond local delimitations.

In recent years, cosmopolitanism has emerged in the context of post-colonial and anti-colonial studies to showcase the importance of non-European cultures, but also as a response to globalisation at the dawn of the 21st century (Mignolo 2011). Regarding the latter, one of the most vocal proponents of cosmopolitanism on a global scale is the German sociologist Ulrich Beck. In his works, Beck introduces a temporal element conceived as "reflexive modernisation". This element is manifested in the emergence of unanticipated global events during the process of globalisation, towards which societies must react simultaneously (Beck 1999). A revived cosmopolitanism is, according to Beck, necessary to recognise the Other and eliminate cultural biases.

Beck argues that "only the cosmopolitan outlook adequately fits with reality and provides an adequate basis for action" $(2005,111)$. In this context, cosmopolitanism is utilised as a methodological tool to describe a globalised world emerging in phenomena that highlight the interconnectedness between societies (Beck 2002). Beck refers to events like the terrorist attacks of $9 / 11$, climate change, and social insurrections like the Arab Spring, calling for a critique of the national paradigm that he deems inadequate to analyse these phenomena (Beck 2012).

Still, Beck's theory of cosmopolitanism bears the traits of a Eurocentric tradition and, as such, is a modernised version of Kantian cosmopolitanism (Bhambra 2010). His conception of Us and the Other seems fixed in preconceived geographical and cultural divisions. He also tends to downplay other fields of social struggle and inequality, like class divisions, the division between global North and South, and the primacy of capitalist centres over the global periphery. Thus, his cosmopolitan outlook does not transcend the hierarchy of global westernised culture over local indigenous cultures. Beck's advocating for tolerance and recognition of the Other fails to integrate cultural diversity in a culturally equitable level of global interconnectivity. Instead, he follows a traditional centre/periphery model that complies with the dominant capitalist imaginary.

Gerard Delanty stresses the reflexive and internalised dimensions of Beck's reevaluation of cosmopolitanism. He calls for a new cosmopolitan imagination that focuses on a variety of possible combinations between locality and globality, instead of reasserting the dominance between the centre and the periphery (Delanty 2006). According to Delanty, "the notion of critical cosmopolitanism sees the category of the world in terms of openness rather than in terms of a universal system. It is this that defines the cosmopolitan imagination" (2006, 38). However, Delanty's critical approach seems to obscure the conceptual foundations of cosmopolitanism, since the notions of centre and periphery are presupposed and thus cannot be transcended in this context.

\subsection{Internationalism}

The revolutions of the 18th century gave birth to modernity, which inspired the impending dominant form of societal and political organisation: nationality. Nationality is directly linked to territory and politicises social features of locality, such as indigeneity, nativity, custom and language. It is correlated to a sense of common past, while nations are historical constructs not of universal necessity; rather, they 
are limited and sovereign imagined political communities (Renan 1996; Gellner 1983; Anderson 1991).

As a fabricated intermediate between locality and universality, nationality is neither existential nor immanently transcendental. In principle, nationality is opposed to universality. Its dependence on territory and homogeneity negate any appeal to the universal. On the contrary, each nation-state is considered as an independent entity that is at war with other self-consistent, independent entities (Schmitt 2007).

The national fragmentation of universality does not favour locality either. The transition of political decision-making from the community to the state has deprived locality of any power. A base level of representation is of course left to local communities, which are the foundations of state legitimacy. Therefore, nationality disrupts the conjunction between locality and universality by substituting for their political and social dimensions.

Nationality is a measure of determination and an arbitrary formation of identity. Communities can become part of different nations, while nations can never become universal. Balibar and Wallerstein point out that 'the concept of 'nation' is related to the political superstructure of this historical system [capitalist world-economy], the sovereign states that form and derive from the interstate system" $(1991,78)$.

Internationalism arose as an attempt to address this issue by transfiguring and recapturing universality in the context of national politics. This was the form that universalism took in the age of nation-states. Internationalism acknowledges the dominance of the nation-state paradigm and proposes equality and solidarity among nations, appealing to a sense of human universality (Nordlinger 2013).

This type of internationalism emerged emphatically on the historical scene after the formation of the International Workers' Association in 1864, which united the whole spectrum of the revolutionary movement, from Marxists to anarchists. Internationalism has been an essential feature of emancipatory social movements that, at times, have managed to overcome national limitations and question the boundaries of nationality.

Another form of internationalism, related to markets and not to peoples' rights, has been promoted by the expansion of capitalism. In 1843, while the British Empire was expanding, advocates of Free Trade like Richard Cobden (1908) argued for a Smithian version of internationalism that could be realised by connecting world markets. After the collapse of the Soviet 'Iron Curtain' in 1991, financial capitalist networks have expanded across the globe, a process that has been labelled "globalisation" (Bresser-Perreira 2008). However, this internationalist agenda did not reduce, but rather intensified the contradictions of nation-state capitalism: the division between directors and executants; the division between native and foreigner; social inequalities and divisions of race and gender; and the dichotomy between internal space, i.e. the space of state jurisdiction, and external space, i.e. the space of international relations.

The invention of the telegraph, the radio and later digital communication technologies made universality tangible in the form of globality. Globality is the sense of a common world, restricted to our planet. It fills universality with concrete experience, creating global infrastructures that provide an empirical foundation. Globality provides locality with a global length to project its activities, and renders universality an actualised potential, above the level of local individuation. It is over the international communication infrastructure of globality, known in the digital age as Information and Communication Technologies (ICT), that globalisation's private profit-driven network of corporations can constitute a global market. 
An alternative to globalisation was offered by Roland Robertson (1995), who first proposed the term "glocalisation" in the late 1980s. This notion describes products or services that are distributed globally and take into consideration the needs of local users (Mendis 2007). In its business sense, glocalisation is connected with micromarketing and the construction of differentiated "consumer traditions" (Robertson 1995, 29). However, Robertson broadens the meaning of glocalisation to offer a new articulation of the relation between the global and the local in terms of simultaneity and interpenetration (1995). For Robertson, "glocalisation means the simultaneity the co-presence - of both universalising and particularising tendencies" $(1997,220)$. $\mathrm{He}$ tries to transcend the tension between globalisation and localisation by emphasising the production of heterogeneity over the surface of homogeneity that globalisation projects. Robertson invites us to embrace heterogeneity, albeit in the homogenous acceptance of a top-down approach, since capitalistic processes of globalisation and glocalisation are driven by international directories and corporations.

In our view, glocalisation is a concept that proceeds from the universal to the local, thus obscuring local diversities and resistances that may be found in the tensions between globalised mechanisms and local authorities. In that manner, glocalisation remains rooted in its business origins and tied to micro-marketing and diverse advertising practices and thoughts, without putting into question the core capitalist motives behind globalisation/glocalisation. As a top-bottom theory it provides a methodological tool to describe the potential of capitalist expansion in a diverse world, but misses the potential for a post-capitalist transition.

As the ICT era matures, a new form of universality called cosmopolitan localism or cosmolocalism is emerging. Building on the criticism of corporate capitalism and global value chains, this new form transfigures the existential, the social and the political across the axis of locality and universality.

\subsection{Cosmolocalism}

The concept of cosmopolitan localism or cosmolocalism was pioneered by Wolfgang Sachs, a scholar in the field of environment, development, and globalisation. Sachs is known as one of the many followers of Ivan Illich and his work has influenced the green and ecological movements. In 1992, he edited the Development Dictionary: A Guide to Knowledge as Power, a 'classic' in (post-)development studies. Sachs asserts that cosmolocalism "seeks to amplify the richness of a place while keeping in mind the rights of a multifaceted world. It cherishes a particular place, yet at the same time knows about the relativity of all places" (1992, 124). Cosmolocalism retains 'placedness' linked with locality, while at the same time projecting it globally, without risking its particularity (1992). Hence, cultural and communal diversity flourishes in a context of universal networking. Further, the local remains independent within the interdependent network that constitutes the global, thus promoting autonomy within complementarity on both levels. Contrary to glocalisation, cosmolocalism moves from locality to universality, acknowledging the local as the locus of social co-existence and emphasising the potential of global networking beyond capitalist market rules.

Ezio Manzini, a leading thinker in design for sustainability, has also envisioned workable alternatives for a sustainable society. As a professor in Design for Social Innovation, Manzini focuses on innovative processes and strategies related to production and consumption in the perspective of sustainable development. His recent work, Design, When Everybody Designs: An Introduction to Design for Social 
Innovation, discusses creative communities and emerging forms of collaboration. Manzini (2015) describes cosmopolitan localism as a way to globally link local communities in distributed networks of shared exchange, bringing production and consumption closer together. This form of cosmolocalism is rooted in an emerging productive model that is based on the concept of the 'digital commons' (Bauwens et al. 2019). While it can be argued that organisational structures resembling cosmolocalism yet rooted in the commons may exist, in the context of this article we embrace solely the aforementioned form.

The basic structure of the commons involves three parts in equal and reciprocal interrelation: common resources, which can be technical, cultural, social, or natural; institutions that set the rules of commoning, like open-source licenses or decisionmaking processes; and the communities involved in the (re)production of the commons (Bollier and Helfrich 2015).

The process of digital commoning was first exemplified by open knowledge projects such as the free encyclopedia Wikipedia and other open-source software projects (Benkler 2006). The second wave is related to open design and manufacturing (Kostakis et al. 2018). In this setting, the design is developed and shared as a global digital commons, while manufacturing takes place locally (Bauwens et al. 2019; Kostakis et al. 2015; Ramos 2017). Several technology initiatives that are small-scale and oriented towards resilience have been applying cosmolocal practices. Such initiatives include WikiHouse (buildings), RepRap (3D printers), OpenMotors (vehicles), OpenBionics (robotic and prosthetic hands) and L'Atelier Paysan (agricultural tools). Practically speaking, the latter initiative utilises a global pool of knowledge to produce farming tools locally but also expands this pool with its own contributions (in terms of designs, know-how and practices). Such a form of cosmolocalism has the potential to address the dependence of local communities on global value chains for its subsistence and the global corporate extractive model that spurs global warming.

Cosmolocalism relies on the same means of information production that support capitalist globalisation, i.e. communications, computation, sensors, and electronic storage (Kostakis and Giotitsas 2020). What distinguishes cosmolocalism from capitalist globalisation is mostly its set of values and principles: reciprocity and selforganisation that respect individual autonomy, local particularity and cultural diversity; sharing that acknowledges commonality and mutual responsibility; collaboration that allows for public deliberation and reflection; and for-benefit orientation that offers a sense of social common good. In this sense, the commons are a necessary condition for cosmolocalism.

Cosmolocalism is not characterised by the external/internal dichotomy that was imposed on internationalism by the dominant nation-state paradigm; instead it is characterised by modes of association that unify local communities without reducing their locality (Bauwens et al. 2019). Locality, being detached from territoriality, becomes purely cultural, correlated to language and custom; the common pool of resources created by the shared practices of commoners across their association preserves every local particularity in a plural, multivocal context where every commoner can equally and freely contribute. This collective, open and equal value production and distribution runs contrary to capitalism's profit-motivated economy. Whereas the latter establishes an exploitative and extractive method of using valuable resources in favour of profit, commons-based peer production establishes a contrary, generative method of sustaining and creating valuable resources in favour of mutual social benefit (Bauwens et al. 2019). 
Is cosmolocalism inherently anti-capitalist? As we have mentioned, it has been argued that cosmolocalism may be reduced to a tech trend (Ramos 2019). However, we argue that this danger is the result of a failure to fully realise the potentials of cosmolocalism. In content, context and principle, cosmolocalism challenges the core values of capitalism. In reality, it puts into question the primal drive and motivation of the capitalist imaginary, the primacy of profit and "the central imaginary signification of capitalist development" (Arnason 1989, 328).

Sachs has argued that the development discourse mobilises key concepts that crystallise "a set of tacit assumptions which reinforce the Occidental world-view" $(1992,4)$. The same critique can also be applied to Beck's cosmopolitanism. Sachs recognises that the significations of capitalist development have both shaped our worldview in a westernised mould and inspired devastating exploitative policies that "evidently failed as a socioeconomic endeavour" (Sachs 1992, 5). Sachs invites us to test the developmental model of reality by realising cosmolocalism. In that sense, cosmolocalism challenges not only capitalist practices, but also the dominant perception of social-historical reality as defined by basic capitalist imaginary significations. In our view, the potential of a cosmolocalist worldview encompasses an anti-capitalist set of values, a non-capitalist mode of co-operation and a postcapitalist horizon of expectations.

Through open contributory practices and the equal distribution of resources, cosmolocalism establishes a new mode of community that is not based in territoriality but in equal participation (Bauwens et al. 2019). This is made possible through its resilient infrastructures, which provide open communication channels and ways of sharing knowledge, techniques and practices.

The decisive novel element that cosmolocalism brings is a radical reconfiguration of existing modalities (Bauwens et al. 2019). This creates alternative forms of social relations based on the direct connection of locality and globality in a horizontal and reciprocal manner. For Manzini, this kind of cosmopolitan localism is capable of creating a new sense of place that forms the ground for instituting a community. Escobar (2018) argues that this new sense of place, i.e., a new set of relations between individuals and their spatial surroundings, implies a dynamic reinvention of the communal.

\section{Understanding the Transition Dynamics of Cosmolocalism}

Cosmolocalism appears to be a promising form of universalism. It appropriates the emancipatory elements of cosmopolitanism while averting most limitations of internationalism. Cosmolocalism transcends national restrictions towards globality, while at the same time acknowledging and empowering locality. It takes full advantage of the liberatory aspects of ICT, allowing for global collaborative production in an equipotential way. Moreover, it reinvents the sense of community and commonality in an open, egalitarian and plural manner.

As seen in existing 'digital commons' communities, cosmolocalism promotes different forms of co-existing, and inspires alternative modes of production based on the commons. As a mode of collaborative production it provides for more resilient and functioning networks that can revive local economies and promote a commonsbased form of collaboration. In this setting, the profit-incentive is downgraded in favour of communal values. Thus, cosmolocalism permits a different transfiguration of locality and universality that allows us to envision new ways towards social equality and justice, without sacrificing diversity and plurality. 
Nevertheless, several aspects of cosmolocalism, such as its socio-environmental implications, require further exploration. For instance, cosmolocalism is highly dependent on ICT, whose proliferation is linked to complex production relations and the new division of digital labour (Fuchs 2013; 2014). Thus, a thorough investigation of cosmolocalism from a political ecology perspective seems essential. Also of paramount importance is the research and support of the emerging institutions that navigate the practicalities of such a configuration.

In the sphere of politics, cosmolocalism remains ineffective and supplementary to the established system. A reinvented sense of the communal, as advocated by the proponents of cosmolocalism, cannot stand without a political dimension. It would be a Marxist naiveté to reduce the political or cultural sphere of society to modes of production. Society is not solely a system of value production and distribution. It is rather a magma of social imaginary significations that give meaning to social coexistence and individual existence.

A political community does not have to be bound to a territory. Rather, it can use its shared values and norms as a core binding authority (Svensson 2011). Therefore, the required political dimension should be instituted according to the set of values that constitute the ground of cosmolocalism. Jose Ramos, a scholar investigating the commons from a future studies perspective, has explored the political dimension of cosmolocalism focusing on the questions of leadership (2017). He has since raised the question of the sustainability of cosmolocal enterprises in the dominant capitalist political economy, pointing to examples like an open insulin project in Oakland that aspires to avoid dealing with corporate enterprises (Ramos 2019). Such examples, along with the danger of the capitalist assimilation of cosmolocalism as a technological trend, highlight an inner dilemma of cosmolocal enterprises in commons production; will they comply with capitalist rules and become sustainable, or refuse capitalist rules and risk the viability of their projects? Ramos suggests creating a different political economy of the commons by creating modes of scale cooperation between different types of commoning. He stresses the significance of 'urban commons' for the creation of a polycentric governance, where political institutions and civil society could reciprocate (2019).

The ways in which cosmolocalism can be adapted to existing political institutions and schemata has not been thoroughly investigated. The rules of capital have a political dimension that is expressed in the state's jurisdiction over individual and collective activity in terms of taxation, licensing and citizenship. While dominant political institutions maintain and reproduce established authority, social inequalities are institutionalised and integrated within state bureaucracies. An alternative form of governance may only be possible with the adequate political institutions.

Current representative political institutions incorporate authoritarian hierarchies and thus are opposed to the principles of cosmolocalism and the commons. Bauwens et al. suggest that a "partner state" would enable "the contributory equipotentiality of all citizens" $(2019,59)$. Given the cosmolocal character of commons-oriented networks, a partner-state would no longer be a nation-state, since citizenship would not depend on nationality. If it continued to depend on nationality, the equipotentiality of all citizens would be limited due to effects on ethnic minorities.

A commons-based configuration of the relation between locality and globality breaks down if we insert the national element. Nationality, being the dominant category of political representation and political power, draws to itself all elements of locality and globality, rendering their interdependence irrelevant. Cosmolocal and translocal networks form unbounded communities consisting of local units. Still, their 
territories are under the jurisdiction of a nation-state. As in the case of internationalism, cosmolocalism seems to be suffering from dependence on nationality, albeit in a more implicit manner. This dependence prevents cosmolocal networks from directly addressing global or multinational challenges, such as the exploitation of natural resources that rely on centralised state decisions. Murdock (2018) stresses the contradictory role of the state, asserting that a commons-based productive model is a core, but not an efficient condition for the transition beyond capitalism. He thus calls us to think upon the limitations inherent to the contradictions between the state and its citizens.

Bauwens and Ramos (2018) have shed light at the city level, exploring their potential transnational combination. This proposal supplements the nation-state apparatus with transnational institutions and networks that have a cosmolocal direction. The idea of a partner-city seems more fruitful than the partner-state, since 'urban commons' are a more tangible and immediate form of horizontal co-existence. Cities can act as transnational entities that are embedded in different national states while retaining certain levels of political decision locally, and "allied leagues of cities can become a partner-state form that commoners require" (Bauwens and Ramos 2018, 338).

We argue for a more radical approach in perceiving the full political scope of cosmolocalism beyond established authorities and hierarchical norms. Cosmolocalism would need to envision a different mode of political power that does not lean on the nation-state paradigm. Kioupkiolis, underlining the need for a focus on the political, argues for a counter-hegemonic politics related to the commons (2019). This entails a perspective to politics that has emerged in the 21 st century along with social movements aspiring to direct democracy.

The social movements that have risen globally against neoliberal capitalism and nation-state authorities in the 21st century present us with a politically enriched view of cosmolocalism. From the anti-globalisation or alter-globalisation movements of the early 2000s to the insurrections in Chile and Hong Kong that began in 2019 and continued well into 2020, they refute and refuse traditional representation mechanisms, formulating informal channels of communication that bridge the local and the global, the particular and the universal, transgressing the national level of state politics.

In the political context of direct democracy, society is self-governed by the equal participation of every individual in political decisions and functions. Direct democracy is a mode of self-governance that is rooted in locality and personal participation and based on equality and autonomy. Further, it is projected globally through the networking of autonomous local political units on both regional and transnational levels. It could be argued that direct democracy provides a cosmolocal approach to political power and authority in the sense that it is a political enactment of the same core values of autonomy, freedom, equality and reciprocity. However, certain political institutions that would enable direct democracy need to be developed.

The transparency of political decisions and subsequent collective actions should be guaranteed by public deliberation and free speech within the public space of decision-making. Information centres should ensure that information flows downwards, from administrative institutions to the base, and that decisions are transmitted upwards, from the base to political institutions (Castoriadis 1997). Digital commons have already created protocols that ensure the open flow of information and make available different ways of networking, using modularity, heterocracy, mutuality and open communication. 
In all, there are three political theories of the commons: the liberal, the reformist and the anti-capitalist (Papadimitropoulos 2017). The liberal theory foresees the commons as another layer added to the current stage of capitalism, and the anticapitalist theory postulates a drastic rupture with the current system. Hence, it is only the so-called reformist theory that develops a deep transition from capitalism to a cosmolocalism model based on the commons.

Cosmolocalism advances alternatives that could potentially undermine dominant capitalist imaginary significations, attitudes and modalities. It can lead the way for a transition towards a post-capitalist, commons-centric economy and society where value is collectively created and accessible to all. In order for cosmolocalism to become more than a blueprint for a mode of production, the autonomy of local communities and individuals is essential. Cosmolocalism could provide resilient communicational and productive infrastructures that would enable social autonomy on a global scale. Its political potential is yet to unfold, but it is worth reflecting upon both in theory and in practice.

\section{References}

Anderson, Benedict. 1991. Imagined Communities: Reflections on the Origin and Spread of Nationalism. London: Verso.

Armstrong, David Malet. 1989. Universals: An Opinionated Introduction. Boulder: Westview Press.

Arnason, Johann P. 1989. Pour une Philosophie Militante de la Démocratie. Revue Européenne des Sciences Socials 27 (86): 323-337.

Balibar, Étienne. 1995. Ambiguous Universality. Differences: A Journal of Feminist Cultural Studies 7 (1): 48-59.

Balibar, Étienne and Immanuel Wallerstein. 1991. Race, Nation, Class, Ambiguous Identities. London: Verso.

Bauwens, Michel, Vasilis Kostakis and Alexandros Pazaitis. 2019. Peer to Peer: The Commons Manifesto. London: University of Westminster Press. Accessed September 3, 2020. https://tinyurl.com/y6hi5ec7

Bauwens, Michel and Jose Ramos. 2018. Re-imagining the Left Through an Ecology of the Commons: Towards a Post-Capitalist Commons Transition. Global Discourse 8 (2): 325342.

Beck, Ulrich. 2012. Redefining the Sociological Project: The Cosmopolitan Challenge. Sociology 46 (1): 7-12.

Beck, Ulrich. 2005. Power in the Global Age. Cambridge: Polity Press.

Beck, Ulrich. 2002. The Cosmopolitan Society \& Its Enemies. Theory, Culture \& Society 19 (1-2): 17-44.

Beck, Ulrich. 1999. World Risk Society. Cambridge: Polity Press.

Benkler, Yochai. 2006. The Wealth of Networks: How Social Production Transforms Markets and Freedom. New Haven: Yale University Press.

Bhambra, Gurminder K. 2010. Sociology after Postcolonialism: Provincialized Cosmopolitanisms and Connected Sociologies. In Decolonizing European Sociology: Transdisciplinary Approaches, edited by Encarnación Gutiérrez Rodriguez, Manuela Boatcă, and Sérgio Costa, 33-48. Farnham: Ashgate.

Bollier, David and Silke Helfrich. 2015. Patterns of Commoning. Amherst: Levellers Press.

Bresser-Pereira, Luiz Carlos. 2008. Globalization, Nation-state and Catching Up. Brazilian Journal of Political Economy 28 (4): 557-576.

Casey, Edward S. 1998. The Fate of Place. A Philosophical History. Berkeley: University of California Press.

Castoriadis, Cornelius. 1997. The Castoriadis Reader. Translated by D. A. Curtis. London: Wiley-Blackwell. 
Cobden, Richard. 1908. Speeches on Questions of Public Policy. London: T.Fisher Unwin.

Delanty, Gerard. 2006. The Cosmopolitan Imagination: Critical Cosmopolitanism and Social Theory. The British Journal of Sociology 57 (1): 25-47. Accessed September 3, 2020. https://oneworlduv.com/wp-content/uploads/2011/06/cosmopolitan imagination.pdf

Donnelly, Jack. 2007. The Relative Universality of Human Rights. Human Rights Quarterly 29 (2): 281-306.

Escobar, Arturo. 2018. Designs for the Pluriverse: Radical Interdependence, Autonomy, and the Making of Worlds. Durham: Duke University Press.

Fuchs, Christian. 2014. Digital Labour and Karl Marx. New York: Routledge.

Fuchs, Christian. 2013. Theorising and Analysing Digital Labour: From Global Value Chains to Modes of Production. The Political Economy of Communication 1 (2): 3-27. Accessed June 4, 2020. http://www.polecom.org/index.php/polecom/article/view/19

Gellner, Ernest. 1983. Nations and Nationalism. Ithaca: Cornell University Press.

Hare, Richard Mervyn. 1991. The Language of Morals. Oxford: Clarendon Press.

Heidegger, Martin. 1999. Contributions to Philosophy (From Enowning). Translated by Parvis Emad and Kenneth Maly. Bloomington: Indiana University Press.

Kant, Immanuel. 1795/1991. Perpetual Peace: A Philosophical Sketch. In Kant's Political Writings, edited by Hans Reiss, 93-131. Cambridge: Cambridge University Press.

Kioupkiolis, Alexandros. 2019. The Common and Counter-Hegemonic Politics. Edinburgh: Edinburgh University Press.

Kleingeld, Pauline. 1999. Six Varieties of Cosmopolitanism in Late Eighteenth-Century Germany. Journal of the History of Ideas 60 (3): 505-524.

Kostakis, Vasilis and Christos Giotitsas. 2020. Small and Local Are Not Only Beautiful; They Can Be Powerful. Antipode Online. Accessed June 4, 2020. https://antipodeonline.org/2020/04/02/small-and-local/

Kostakis, Vasilis, Kostas Latoufis, Minas Liarokapis and Michel Bauwens. 2018. The Convergence of Digital Commons with Local Manufacturing from a Degrowth Perspective: Two Illustrative Cases. Journal of Cleaner Production 197 (2): 1684-1693.

Kostakis, Vasilis, Vasilis Niaros, George Dafermos, and Michel Bauwens. 2015. Design Global, Manufacture Local: Exploring the Contours of an Emerging Productive Model. Futures 73: 126-135.

Manzini, Ezio. 2015. Design, When Everybody Designs: An Introduction to Design for Social Innovation. Cambridge, MA: MIT Press.

Mendis, Patrick. 2007. Glocalization: the Human Side of Globalization. Morrisville: Lulu Press.

Mignolo, Walter D. 2011. Cosmopolitan Localism: A Decolonial Shifting of the Kantian's Legacies. Localities 1 (1): 11-45.

Murdock, Graham. 2018. Commons Manifestos: A Reply to Bauwens and Ramos. Global Discourse 8 (2): 343-347.

Nordlinger, Jay. 2013. Peace They Say: A History of the Nobel Peace Prize, the Most Famous and Controversial Prize in the World. New York: Encounter Books.

Nussbaum, Martha C. 1997. Kant and Stoic Cosmopolitanism. The Journal of Political Philosophy 5 (1): 1-25.

Nussbaum, Martha C. 1994. Patriotism and Cosmopolitanism. The Boston Review. Accessed June 4, 2020. http://bostonreview.net/martha-nussbaum-patriotism-andcosmopolitanism

Papadimitropoulos, Vangelis. 2017. The Politics of the Commons: Reform or Revolt? tripleC: Communication, Capitalism \& Critique 15 (2): 563-581. Accessed June 4, 2020. https://www.triple-c.at/index.php/tripleC/article/view/852

Ramos, Jose. 2017. Cosmo-Localization and Leadership for The Future. Journal of Future Studies 21 (4): 65-84.

Ramos, Jose. 2019. Cosmo Localism: Tech Trend, Post Capitalist Commons Transition or Something Else? Medium. Accessed June 4, 2020. 
https://medium.com/@joseramos 30450/cosmo-localism-tech-trend-post-capitalistcommons-transition-or-something-else-4dc0202dd732

Renan, Ernest. 1996. What is a Nation? In Becoming National: A Reader, edited by Geoff Eley and Ronald G. Suny, 41-55. Oxford: Oxford University Press.

Robertson, Roland. 1997. Comments on the 'Global Triad' and Glocalisation. In Globalisation and Indigenous Culture, edited by Nobutake Inoue, 217-225. Tokyo: Institute for Japanese Cultural Classics.

Robertson, Roland. 1995. Glocalization: Time-Space and Homogeinety-Heterogeneity. In Global Modernities, edited by Mike Featherstone, Scott Lash and Roland Robertson, 2544. London: Sage.

Sachs, Wolfgang. 1992. The Development Dictionary: A Guide to Knowledge as Power. London: Zed Books.

Schismenos, Alexandros. 2019. Direct Democracy, Social Ecology and Public Time. In Social Ecology and the Right to the City, edited by Federico Venturini, Emet Değirmenci and Ines Morales, 128-141. Montreal: Black Rose Books.

Schmitt, Carl. 2007. The Concept of the Political. Translated by George Schwab. Chicago: University of Chicago Press.

Svensson, Jakob. 2011. Theorizing Citizenship in Late Modern ICT Societies. tripleC: Communication, Capitalism \& Critique 9 (2): 644-656. Accessed June 4, 2020. https://www.triple-c.at/index.php/tripleC/article/view/195

\section{About the Authors}

Alexandros Schismenos

Alexandros Schismenos earned his Ph.D. in Philosophy from the University of Ioannina in 2017. Currently he is a post-doctoral researcher at the Aristotle University of Thessaloniki.

Vasilis Niaros

Vasilis Niaros is a Research Fellow at the Urban Transformation and Global Change Laboratory (TURBA) of Universitat Oberta de Catalunya. He holds a PhD in Technology Governance from Tallinn University of Technology (2016).

Lucas Lemos

Lucas Lemos is a Junior Research Fellow at Tallinn University of Technology. 